\title{
Oppimisympäristöt syrjäytymisen ehkäisyssä
}

Heleena Lehtonen (toim.) Sytykkeitä syrjäytymisen ehkäisemiseen. Tampereen yliopisto. Opettajankoulutuslaitos. Hämeenlinnan yksikkö. 2008. 187 s.

Suomessa, PISAN huippumaassa, teos Sytykkeitä syrjäytymisen ehkäisemiseen on erittäin ajankohtainen. ”Koulumaailmassa eletään haasteellista aikaa. Oppiminen ja koulutus ovat polarisoitumassa. Osa nuorista suoriutuu opinnoista loistavasti ja päämäärätietoisesti, osa jättäytyy koulutuksen ulkopuolelle ja suhtautuu kyynisesti tulevaisuuteen. Polarisoitumisen vähentämiseksi tarvitaan monipuolisia toimia. Tarvitaan kasvattajien, tutkijoiden ja hallinnon yhteistyötä kehittämään koulukulttuuria erilaisten opiskelijoiden kasvua tukevaksi”, todetaan osuvasti teoksen esitteessä.

Teoksessa kuvataan syrjäytymisen ehkäisyn SYTYKE-projektia, joka laajeni toimijoiden käsissä yli hallintorajojen ulottuvaksi moniammatilliseksi toiminnaksi. Teos koostuu hankkeen toimijoiden ja taustavaikuttajien artikkeleista jakautuen kolmeen osaan. Ensimmäisessä osassa avataan kehittämistoiminnan perusteita käsitteineen, tavoitteita ja toimintamallia sekä esitellään tehtyä osatutkimusta. Toisessa esitellään toimintoja yksityiskohtaisemmin. Teos päättyy analysoivaan pohdintaan hankkeesta koulukulttuurin muutostekijöinä.

Merkittävää on se, että toimijoita on ollut koulutuksen kaikilta asteilta: perusasteelta yliopistoon, sosiaali-, terveys- ja nuorisotoimesta sekä kolmannesta sektorista. Kukin kirjoittaja on kuvannut toimintaa oman sektorin näkökulmasta.

Avausartikkelissa Ilkka Vertasen käsittelee syrjäytymisprosessin etenemistä ja osatekijöitä, hän erittelee myös syrjäytymisen käsitettä ja taustoja. Vertanen toteaa, että syrjäytyminen on prosessi, joka kehittyy vähitellen ja koostuu monien eri tekijöiden kasaantumisena. Syrjäytymisen ongelma syntyy, kun ihminen ajautuu ulos keskeisiltä yhteiskunnallisilta foorumeilta kuten koulutuksesta, työstä, sosiaalisista suhteista, osallisuudesta ja vaikuttamisesta. Syrjäytyminen etenee usein koulutuksellisen ja sosiaalisen syrjäytymisen kautta yhteiskunnalliseen syrjäytymiseen. Syrjäytymisriskin tunnistaminen antaa kasvattajille mahdollisuuksia ennalta ehkäisevään työhön.

Seuraavaksi Vertanen kuvaa systemaattisesti syrjäytymisen ehkäisyhankkeen lähtökohtia ja tavoitteita. Ydintavoite toiminnassa on ollut oppimisen tukeminen ja oppimisympäristöjen laajentaminen niin, että kaikki oppijat voivat kokea oppimisen mielekkäänä. Kehittämistyön perustaksi ja opettajien sitouttamiseksi on selvitetty koulujen tarpeet syrjäytymisen ehkäisyyn haastattelemalla opettajia ja koulun muuta henkilöstöä. Selvitystyön pohjalta on luotu koulukohtaisia ratkaisuja moniammatilliseksi tukiverkostoksi ja oppimis- ympäristöjen laajentamiseksi ympäröivään yhteiskuntaan. Vertanen päättää artikkelin pohdintaan miten koulukulttuurin kehittämistä tulisi saatujen kokemusten pohjalta jatkaa.

\section{Yrittäjyyskasvatuksesta työkaluja}

Oppimisympäristöjen luomisen kontekstiksi hankkeessa on otettu yrittäjyyskasvatus. Heleena Lehtonen ja Helena Lehkonen argumentoivat artikkelissaan, miksi yrittäjyyskasvatuksen pedagogiikassa nähdään hyviä mahdollisuuksia syrjäytymisen ehkäisyyn. Käsitteistön avaaminen ja yrittäjyyskasvatuksen pedagogiikan pohtiminen mitä-, miten- ja missä-kysymyksin selventää yrittäjyyskasvatuksen merkitystä perusopetuksessa. Kirjoittajat painottavat, että yrittäjyyskasvatuksella perusopetuksessa pyritään tukemaan oppilaiden kasvua yhteiskunnan täysivaltaisiksi ja aktiivisiksi jäseniksi. Yksilön rakentava aktiivinen ja luova toiminta pohjautuu luottamukseen, joka on rikastavan yhteisön perusta. Pekka Himasen rikastavan yhteisön malli on ollut lähtökohtana Lehtosen ja Lehkosen luomalle mallille perusopetuksen yrittäjyyskasvatukseen.

Heleena Lehtosen artikkeli koskee tutkimusta, jossa omaehtoisen yrittäjyyden osatekijöistä nostettiin tarkastelun kohteeksi itseohjautuvuus ja tulevaisuusorientaatio. Artikkelissa syvennetään omaehtoisen yrittäjyyden käsitettä ja eritellään oppi- 
misympäristön tekijöitä, jotka tukevat omaehtoista yrittäjyyttä.

Oppimisympäristön luomisessa tulee painottaa sitä, että ympäristö antaa oppijalle vastuuta ja vapautta, kannustaa oppimaan itse tekemällä, keksimällä, mahdollisuuksia havaitsemalla ja niihin tarttumalla, harkittuja riskejä ottamalla, pitkäjänteisesti ponnistelemalla yhteistyössä toisten kanssa. Tutkimuksen perusteella itseohjautuvuuden kehittäminen on merkittävä tekijä tavoitteisuuden, motivaation ja tulevaisuuden hahmottamisen kannalta. Tutkimus tarjoaa hyvää pohjaa jatkotutkimukselle, jossa tehdään näkyvämmäksi itsesäätelyn osatekijöiden rakenteita ja toimintaa tulevaisuusorientaatiossa.

Sosiaalipedagogiseen orientaatioon ja sosiokulttuuriseen innostamiseen pohjautuvaa ammattikorkean sosiaalialan osallistumista oppimisympäristöjen luomiseen kuvaa Liisa Harakkamäki. Raija Paju ja Saija Honkala puolestaan erittelevät ohjaustoiminnan koulutusohjelman monipuolisia mahdollisuuksia tuottaa toiminnallisia ja luovuutta tukevia oppimisympäristöjä. Artikkelit avaavat innostavasti uusia näkymiä moniammattillisten verkostojen hyödyntämiseen kasvatuksessa. Huomionarvoisia ovat erityisesti teoreettiset perusteet ja käytännön ratkaisut. Toiminta integroidu hyvin hankkeen päämääriin ja tukee taustalla olevaa yrittäjyyskasvatuksen oppimisympäristöjen mallia. Oppinäyte- ja lopputöiden sitominen toimintaan on vahvistanut tutkimuksellista otetta työhön.

Jukka Kemppi kuvaa toimintaa nuoren pudottua kulutuksesta. Osan nuorten syrjäytyminen on edennyt normatiiviseksi ja kri- minalisoituminen on alkanut. Opettajan rehellistä puhetta haasteellisten tilanteiden kokemuksista edustaa Pirjo Aholan artikkeli. Hän toteaa, että suuressa koulussa yksilötasolla tapahtuvat asiat eivät välttämättä ulotu vain lähipiirin tietoon ja kehitystä on vaikea mitata perinteisin koulun keinoin. Yhdenkin oppilaan kääntyminen asenteissa koulua kohtaan myönteiseen suuntaan on arvokasta. Rikastavan yhteisön luottamus on tukenut luovuutta etsiä ongelmiin uusia ratkaisuja, uskallusta yrittää epäonnistumisen uhallakin.

Hankkeet koulukulttuurin muutostekijöinä -luvussa analysoidaan hankkeiden mahdollisuuksia olla tienviittoina uuteen kouluun. Koulun näkökulmaa hanketoimintaan avaa Arto Nykänen. Hän pohtii kriittisesti kehittämistoiminnan lähtökohtia; mitä kehittäminen edellyttää koululta, mitä hankkeelta. Hän erittelee kehittämistä koulun rakenteiden, opettajan ja oppijan näkökulmasta ja paljastaa koulun monimuuttujaista maailmaa organisaationa ja kasvuympäristönä. Kirsti Mäensivu näkee koulun perustehtävän ytimessä tukea ihmisenä kasvamista, jota ei voida ohittaa itsestäänselvyytenä. Hän toteaa, että tavoite on nykykoulussa entistä ajankohtaisempi, haasteellisempi ja syvällisempi. Mäensivu nostaa esiin John Quicken puheen identiteetin kehittämisen tärkeydestä. Quicke kiinnittää identiteetin kehittämisen perinteiseen ammatin ja uran valintaan, mutta laajentaa identiteetin koskemaan kansalaisena, miehenä, naisena, oppijana jne. olemista ja kasvamista. Koulun uudistamisen keskeinen kysymys on, miten ratkaistaan oppilaiden ihmisenä kasvamisen liittyvät haasteet.
Teos liittyy tiiviisti keskusteluun koulukulttuurin ja oppimisympäristöjen kehittämisestä. Syrjäytymisen problematiikasta on tullut polttava aihe. SYTYKKEEN toimijat ovat olleet edelläkävijöiden joukossa ennalta ehkäisevässä työssä ja tutkimuksessa. Kirja tarjoaa tutkimuksin ja kokemuksin perusteltua uutta näkökulmaa oppimisympäristöjen avartamiseen ja ihmisen kasvun tukemiseen.

\section{Taimi Tulva}

